\title{
Modalities to Address Legal Impediments to the Citizens'Right to Impart Public Sector Information
}

\author{
Haswira Nor Mohamad Hashim, Anida Mahmood, Fazlin Mohamed Zain, Nurul Shuhada Suhaimi \\ Faculty of Law, \\ Universiti Teknologi MARA, Shah Alam, Selangor, Malaysia
}

haswira648@uitm.edu.my, anidafuu@gmail.com, fazlin.mz@gmail.com, nurulshuhadasuhaimi@gmail.com Tel: +60355443481

\begin{abstract}
This paper conducts a comparative analysis of various modalities currently being adopted in selected countries to address legal impediments to the citizens' rights to impart public sector information (PSI). Previous studies have identified a myriad of laws currently in force in Malaysia which impede the citizens' rights to impart PSI. In the absence of sui generis law on the right to information, disclosure, publication, communication and distribution of PSI is subject to these laws. This paper surveyed to identify the most appropriate modalities for adaptation in Malaysia and later suggested the appropriate modalities to address the legal impediments.
\end{abstract}

Keywords: Legal impediment; Right to information; Modalities; Citizens

eISSN: 2398-4287 @ 2020. The Authors. Published for AMER ABRA cE-Bs by e-International Publishing House, Ltd., UK. This is an open access article under the CC BYNC-ND license (http://creativecommons. org/licenses/by-nc-nd/4.0). Peer-review under responsibility of AMER (Association of Malaysian Environment-Behaviour Researchers), ABRA (Association of Behavioural Researchers on Asians) and cE-Bs (Centre for Environment-Behaviour Studies), Faculty of Architecture, Planning \& Surveying, Universiti Teknologi MARA, Malaysia.

DOI: https://doi.org/10.21834/ebpj.v5iSI1.2322

\subsection{Introduction}

The objective of this paper is to propose modalities to address legal impediments to the citizen's rights to impart public sector information. Citizens have a right to impart information together with the right to seek and receive information (Mishra, 2013). The right to impart information is also a precondition of the freedom of the press and media (Peled \& Rabin, 2011). The citizens' ability to impart public sector information keeps open communication and a continuing dialogue between the Government and the people (Centre for Media Pluralism and Media Freedom, 2016).

Within the context of this study, Public Sector Information (PSI) refers to information produced or held by the Government or for the Government under the law or in connection with official functions, businesses or affairs at federal, state and local government levels (Lor \& Britz, 2007). The Government also has a responsibility to refrain from interfering with the communication of PSI necessary for the exercise of the democratic rights of the citizens (Thiru, 2016). Article 19 of the International Covenant on Civil and Political Rights imposes an obligation on the Government to protect, promote, respect and ensure the citizens' rights to impart information.

Extant literature has identified a myriad of legislation, i.e. the Official Secret Act 1972, Penal Code, Printing Presses Publication Act 1994, Sedition Act 1948 and Evidence Act 1950, which impede the citizens' rights to impart public sector information in Malaysia (Amnesty International, 2015). A whistleblower who disclosed improper conduct in the public sector, though protected under the Whistleblower Protection Act 2010 (WPA 2010), is not allowed to make disclosure directly to the public. Instead, the whistleblower is required to disclose the inappropriate conduct to an enforcement agency, department or other body set up by the Government (Muhamad Izwan, 2014).

Furthermore, s 11(1) (d) WPA 2010 empowers enforcement agencies to revoke protection of the whistleblower if the disclosure involves questioning the merits of government policy. Moreover, s 6(1) WPA 2010 provides any written law must not prohibit the

eISSN: 2398-4287 (C) 2020. The Authors. Published for AMER ABRA cE-Bs by e-International Publishing House, Ltd., UK. This is an open access article under the CC BYNC-ND license (http://creativecommons.org/licenses/by-nc-nd/4.0/). Peer-review under responsibility of AMER (Association of Malaysian Environment-Behaviour Researchers), ABRA (Association of Behavioural Researchers on Asians) and cE-Bs (Centre for Environment-Behaviour Studies), Faculty of Architecture, Planning \& Surveying, Universiti Teknologi MARA, Malaysia.

DOI: https://doi.org/10.21834/ebpj.v5iSI1.2322 
disclosure made under the Act. Therefore, the disclosure of PSI prohibited by the Official Secret Act 1972, Penal Code, Printing Presses Publication Act 1994, Sedition Act 1948 and Evidence Act 1950 would not attract protection under the WPA 2010 (Johan, 2013).

Though the purpose of these legislation is to protect public order, public safety, national interest and security, in practice, these legislation impede the citizens' right to impart PSI (The Malaysian Insider, 2014). In the absence of whistleblower protection, any person who imparts information classified as an affair of State, official communication, prohibited publication or seditious, risks facing prosecution for violating s 8(1)(c),(e),(d) Official Secrets Act 1972 (release or disclosure of official secret); s 203A(1)\&(2) Penal Code (disclosure or subsequent disclosure of any information or matter which has been obtained by a civil servant in the course of his duties, or the exercise of his functions under any written law), s 8(2) Printing Presses and Publication Act 1984 (issuing, circulating and distributing prohibited publication); or s 10(1) Sedition Act 1948 (court order to prohibit the issuing and circulation of prohibited publication).

In addition, s 123 of the Evidence Act 1950 prohibits the production in court of any unpublished official records of affairs of State, or to give any evidence derived therefrom, except with the permission of the head of the department concerned, who shall give or withhold consent as he thinks fit, subject also, to the control of a Minister. Moreover, $s 124$ of the Act prohibits a public officer from being compelled to disclose before the court any communication made to him in official confidence when he considers that public interest would suffer from the disclosure. The Act empowers the Head of the Department of the Government office in question to certify whether disclosure of an official record is prejudicial to the public interest.

All these legislation impede the citizens' rights to impart information, including PSI. Addressing legal impediments to the citizens' rights to impart PSI can improve public trust and confidence in the Government. Protecting, promoting, respecting and ensuring the right to impart PSI is in line with the Malaysian Government transformation program, which emphasises the Government's commitment to transparency and accountability. As there is a lacuna for such modalities, this paper aims to propose modalities to address legal impediments to the citizens' rights to impart PSI in Malaysia. The proposed modalities will ensure that disclosure of PSI becomes a rule and secrecy is an exception.

\subsection{Literature Review}

Review of literature amassed from 2002 to 2007 found that several inter-governmental bodies and civil society such as The UN Special Rapporteur on Freedom of Opinion and Expression, Commonwealth Human Rights Initiative, Article 19 and Open Society Justice Initiative, have laid down general principles of the right to information. These principles served as the international standards to be observed in the legislation that gives effect to the citizens' rights to public information (Daruwala, 2003). During the same period of years, similar and other inter-governmental bodies/civil society alike have started to develop legislative models for the right to information to give effects to this right (African Commission on Human and Peoples Rights 2013; Model Law on Access to Information for Africa African Commission on Human and Peoples Rights; Commonwealth Secretariat; The Latin American Approach to Transparency and Access to Information: ELLA; Commonwealth Secretariat 2002; Commonwealth Heads of Government Draft Model Freedom of Information Bill 2002; Article 19 Model Freedom of Information Law). However, their focus is to develop a sui generis law which is at par with the international standards and general principles of the right to information and not on addressing the legal impediments to the right to impart PSI arising from conflicting laws and policies.

Further review of literature discovers that, none of the previous studies either at the international level or in Malaysia identify the most appropriate modalities to address the legal impediments to citizens' rights to impart PSI. Due to the gap identified in the literature, this research aims to propose modalities to address legal impediments for citizens' rights to impart PSI in Malaysia arising from a myriad of competing laws currently in existence.

Furthermore, as far as Malaysia is concerned, review of literature also found that previous studies, either at the international level (The Constitution Unit UCL, 2011) or in Malaysia (Izwan, 2014; Venkiteswaran, 2010) mostly report about the absence of constitutional and legislative protections for the right to information in Malaysia. The Constitution Unit UCL also studied on the Selangor and Penang Freedom of Information Enactments whereby the study found that the Enactments are subject to the Federal laws including those which impede the citizens' rights to information. Despite the existence of legal impediments to citizens' rights to impart PSI, the previous studies did not propose modalities to address the legal impediments.

\subsection{Methodology}

The research methodology was designed to answer a two-tier research question: i) What are the most appropriate modalities to address legal impediments to the citizens' rights to impart PSI? and ii) How should the modalities be adapted to address legal impediments to the citizens' right to impart PSI in Malaysia? To answer the first research question, this research adopted a mixed-mode approach, comprising fieldwork to collect primary data and library-based research to collect secondary data. Secondary data was drawn from legislative texts (collectively referred to as "the Laws") and non-legislative texts such as policies, procedures and guidelines (collectively referred to as "the Policies") and collected from the official websites of the Governments of selected countries. The countries selected were the United Kingdom (UK), Canada and New Zealand since not only do they share a similar legal system with Malaysia, but similar colonial-era legislation. Altogether, there were 14 laws and three policies collected for analysis.

For the primary data, cross-sectional data were collected from the survey population. The survey questionnaires contained 11 variables, based on a five-point Likert scale ranging from the lowest to the highest (1=Strongly Disagree, 2=Disagree, 3=Not Sure, 4=Agree, $5=$ Strongly Agree). The variables were derived from various modalities underpinning the citizens' rights to impart PSI currently 
being implemented in the UK, Canada and New Zealand. Data collection was conducted from 1 January 2017 to 1 April 2017. The target population for the survey was representatives of a Government agency, an independent statutory body, civil society and academia.

For the selection of the respondents, this research used purposive sampling. The criteria for selection were legal officers who are currently attached to the Government and statutory bodies, members of non-governmental organisations and academics at Malaysian public universities. The survey was conducted with 20 respondents from the Attorney General's Chambers and the Malaysian AntiCorruption Commission. For triangulation, 20 respondents who are civil rights activists and academic experts in constitutional law and human rights law were also surveyed. The researchers had distributed by hand; self-administered survey questionnaires to the target population using a stratified purposive sampling technique. The language of instruction for the survey was English and each respondent was allocated approximately thirty minutes to answer the survey questionnaires.

For primary and secondary legal sources analysis, this research employed a legal doctrinal and policy analysis method. Further, the research adopted a comparative study, built on the modalities from the selected countries based on three criteria: similarities, differences and special/unique features of the modalities in addressing legal impediments to the citizens' right to impart PSI.

In answering the second research question; how should the modalities be adapted to address legal impediments to the citizens' right to impart PSI in Malaysia; the researchers used a normative analysis approach to determine the modalities ought to be applied. As for the quantitative data, the descriptive analysis method was used to analyse the survey data. The nominal data were analysed to find the Mode and the ordinal data were statistically analysed to rank and to find the Median for each variable in the Likert scale, and the Mean used to describe the scale.

\subsection{Result and Discussion}

The figures and tables below illustrate the findings of the survey conducted among 40 respondents in determining the most appropriate modalities to address legal impediments to the citizens' rights to impart PSI.

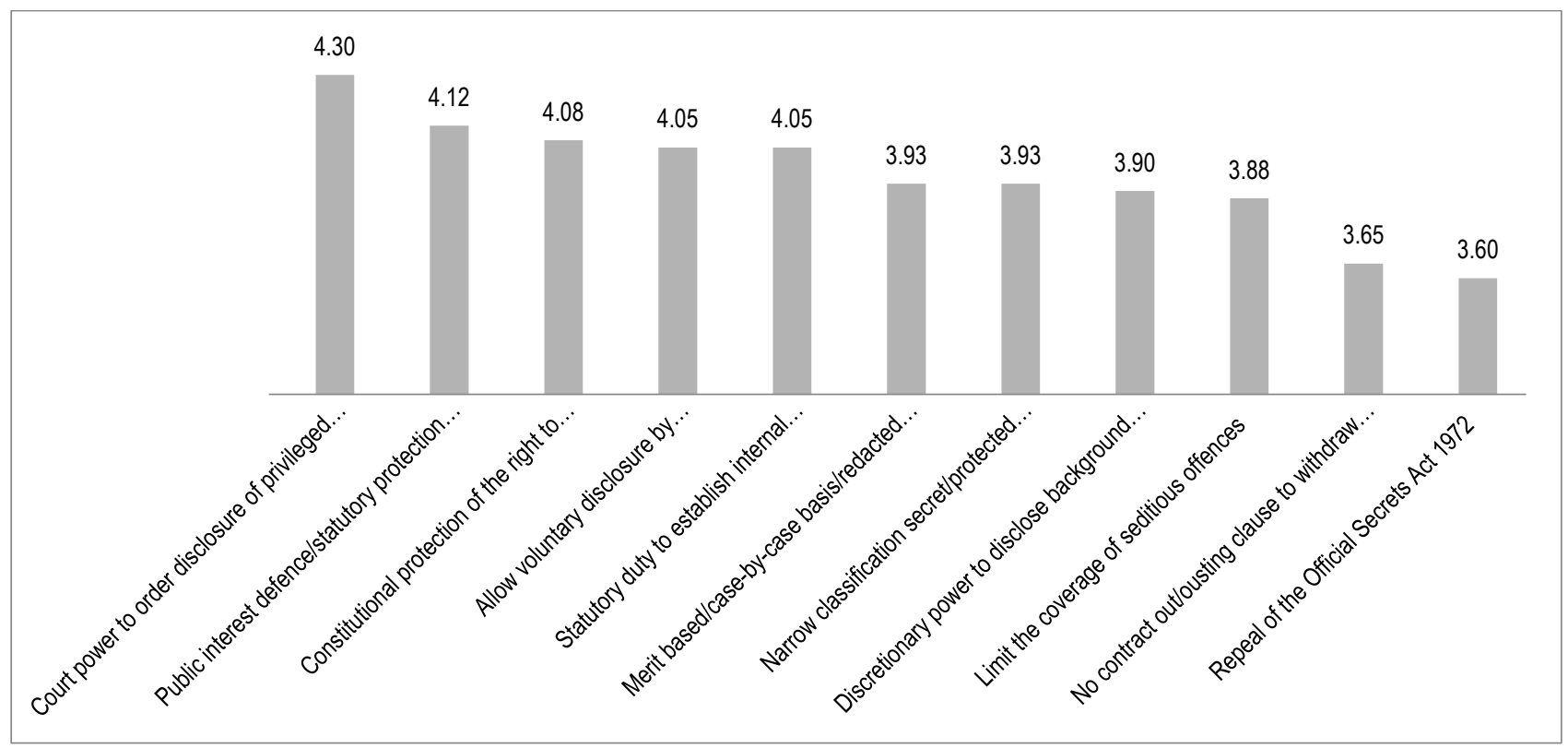

Fig.1. Mean Value

Based on Figure 1, it is found that the highest Mean value is 4.30 (Court power to order disclosure of privileged and confidential information in judicial proceedings) followed by 4.13 (Public interest defence/statutory protection from civil and criminal liability for protected disclosure). The lowest Mean value is 3.60 (Repeal of the Official Secrets Act 1972). The Mean values for all the variables surveyed range from 3.60 to 4.30 . The findings indicate that the respondents of this survey are not entirely in agreement as to the appropriateness of some of the modalities to address legal impediments to the citizens' rights to impart PSI in Malaysia.

Table 1. Total Median of 11 items measuring modalities to address legal impediments to the citizens' rights to impart PSI based on the respondents' organisation

Respondents' Organisation

\begin{tabular}{|c|c|c|c|c|}
\hline & $\mathrm{GA}$ & SB & $\mathrm{CS}$ & $\mathrm{AC}$ \\
\hline $\begin{array}{l}\text { Constitutional protection of the right to impart information including freedom of the press and other media } \\
\text { communication }\end{array}$ & 4.00 & 4.00 & 5.00 & 4.00 \\
\hline $\begin{array}{l}\text { Allow voluntary disclosure by an employee/public servant in good faith to Minister, Ombudsmen, his employer, other } \\
\text { responsible person and public }\end{array}$ & 4.00 & 4.00 & 4.00 & 4.00 \\
\hline
\end{tabular}




\begin{tabular}{|c|c|c|c|c|}
\hline Public interest defence/statutory protection from civil and criminal liability for a protected disclosure & 4.00 & 4.00 & 4.00 & 4.00 \\
\hline $\begin{array}{l}\text { Discretionary power to disclose background information/statement of the reason for administrative/policy decision } \\
\text { making }\end{array}$ & 3.50 & 4.00 & 4.00 & 4.00 \\
\hline Repeal of the Official Secrets Act 1972 & 3.00 & 3.00 & 4.00 & 4.00 \\
\hline Court power to order disclosure of privilege and confidential information in judicial proceedings & 4.00 & 4.00 & 5.00 & 4.00 \\
\hline The statutory duty to establish internal procedures to manage disclosures of PSI & 4.00 & 4.00 & 4.00 & 5.00 \\
\hline Narrow classification secret/protected information & 4.00 & 4.00 & 4.00 & 4.00 \\
\hline Limit the coverage of seditious offences & 3.00 & 4.00 & 4.50 & 4.00 \\
\hline No contract out/ousting clause to withdraw or abandon the right to disclose information & 3.50 & 3.00 & 4.00 & 4.00 \\
\hline Merit-based/case-by-case basis/redacted forms of disclosure of secret and official non-sensitive information & 4.00 & 4.00 & 4.00 & 4.00 \\
\hline
\end{tabular}

Legend of Respondents' Organisation

$\mathrm{GA}=$ Government Agency

$\mathrm{SB}=$ Statutory Body

$\mathrm{CS}=$ Civil Society

$\mathrm{AC}=$ Academia

Table 1 shows the Median value lower than 4.00 from the respondents attached to the government agency in four variables. Those variables are i) Discretionary power to disclose background information/statement of the reason for administrative/policy decision making (3.50); ii) Repeal of the Official Secrets Act 1972 (3.00); iii) Limit the coverage of seditious offences (3.00); and iv) No contract out/ousting clause to withdraw or abandon the right to disclose information (3.50). As for the respondents representing the independent statutory body, Median values lower than 4.00 are recorded for: i) Repeal of the Official Secrets Act 1972 (3.0); and ii) No contract out/ousting clause to withdraw or abandon the right to disclose information (3.0). As for respondents representing civil society, Median values for all variables are 4.00 and above, with two variables showing a Median value of 5.00. High Median value is also recorded from the academia, where the Median value 4.00 is recorded for ten variables, while one variable i.e. 'Statutory duty to establish internal procedures to manage disclosures of PSI' shows a Median value of 5.00. Therefore, it can be concluded that the academia and civil rights activists are more receptive of the modalities to address legal impediments to the citizens' rights to impart PSI compared to the respondents who are attached to a Government agency and statutory body.

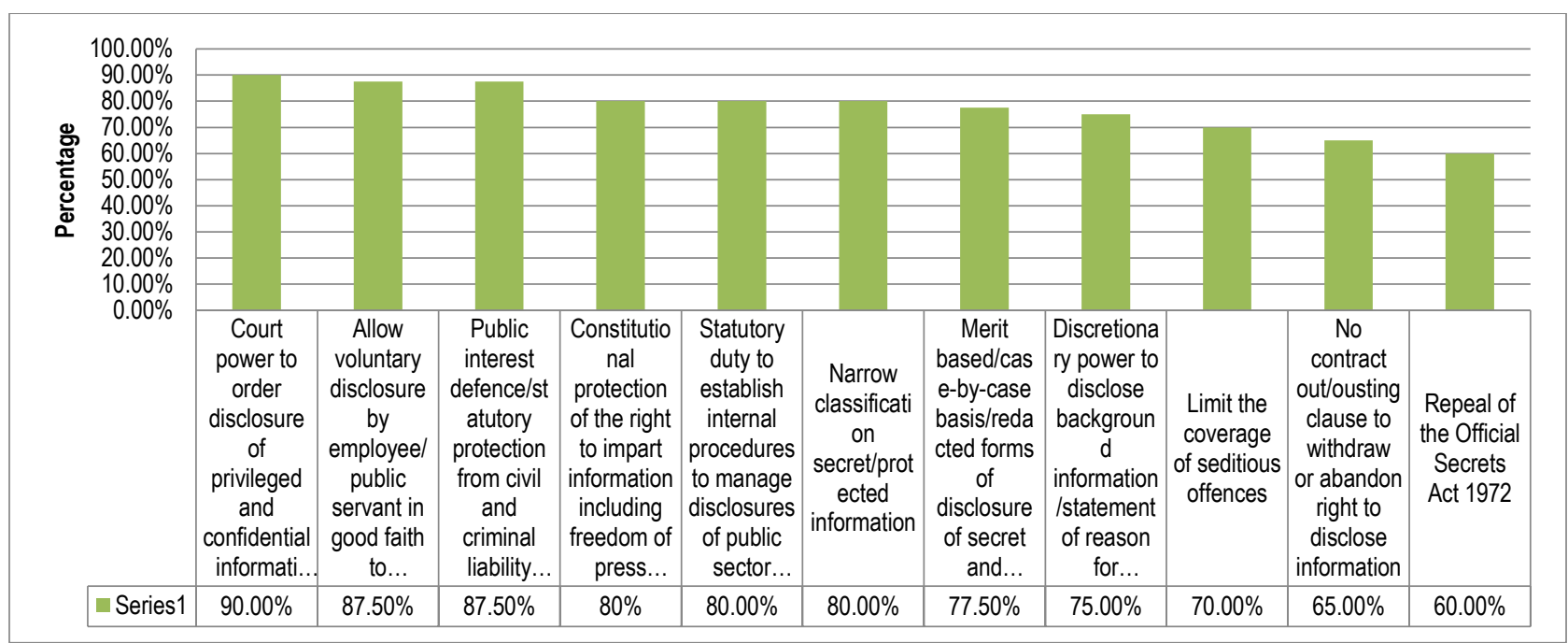

Fig.2. Distribution of percentage agreement of 11 items measuring modalities to address legal impediments to the citizens' right to impart PSI

Figure 2 shows the Mode value for each variable. It is found that 'Court power to order disclosure of privileged and confidential information in judicial proceedings' records the highest Mode value of "Agree and Strongly Agree" at 90.0\%. The lowest Mode value for the "Agree and Strongly Agree" response is for 'Repeal of the Official Secrets Act 1972' (60\%). From the findings above, this study observes that overall, the majority of the respondents either "Agree" or "Strongly Agree" to the appropriateness of the modalities to address legal impediments to the citizens' rights to impart PSI. Therefore, all variables from the survey can be incorporated as modalities to address legal impediments to the citizens' rights to impart PSI in Malaysia. 


\subsection{Proposal}

Table 2 below contains a set of a proposal on the modalities to address legal impediments to the citizens' rights to impart PSI in Malaysia. The main purpose of proposing these modalities is to provide a means to address legal impediments to the citizens' rights to impart PSI in Malaysia. The proposed modalities comprised of legislative and non-legislative measures with high Mean and Median values in the survey. This research also propose a constitutional amendment as $80 \%$ of the respondents agree that the citizens' rights to impart information is one of the most appropriate modalities to address the legal impediments.

Table 2. Modalities to Address Legal Impediments to the Citizens' Rights to Impart PSI in Malaysia (Legislative Measures)

\begin{tabular}{|c|c|}
\hline & Legislative Measures \\
\hline 1. & $\begin{array}{l}\text { To amend Article 10, Federal Constitution (Malaysia) by adapting Art 14, Bill of Rights Act } 1990 \text { (NZ) and Art 10(1), Human Rights Act } 1998 \text { (UK), which } \\
\text { recognise the freedom to hold, receive and impart information without interference by public authority and regardless of frontiers. }\end{array}$ \\
\hline 2. & $\begin{array}{l}\text { To amend s } 6(1) \text {, Whistleblower Protection Act } 2010 \text { (WPA 2010) by adapting s } 10(1)(\mathrm{a}) \text { - }(\mathrm{c}) \text {, Public Disclosure Act } 2000 \text { (NZ) that allows disclosure to be } \\
\text { made to the public if the person or appropriate authority to whom the disclosure was first made: } \\
\text { - has decided not to investigate the matter, or } \\
\text { has decided to investigate the matter but has not made progress with the investigation within a reasonable time, or } \\
\text { has investigated the matter but has not taken any action in respect of the matter. }\end{array}$ \\
\hline 3. & $\begin{array}{l}\text { To adapt s } 16(a),(b) \text {, Public Servants Disclosure Protection Act } 2005 \text { (Canada) which allows disclosure to the public if there is insufficient time to disclos } \\
\text { to the designated parties, and the subject-matter of the disclosure is an act or omission that constitutes a serious offence under an Act or constitutes an } \\
\text { imminent risk of substantial and specific danger to the life, health and safety of persons, or the environment. }\end{array}$ \\
\hline 4. & $\begin{array}{l}\text { To amend the proviso to s } 6(1) \text {, WPA } 2010 \text { by substituting the existing provision with an overriding provision: } \\
\text { "The statutory right and protection given under WPA } 2010 \text { shall prevail over other laws currently in force, provided the disclosure is made in the public's } \\
\text { interest." }\end{array}$ \\
\hline 5. & $\begin{array}{l}\text { To adapt s 15(1), Security of Information Act } 1985 \text { (Canada) on the public interest defence test: the public interest in the disclosure outweighs the public } \\
\text { interest in non-disclosure. }\end{array}$ \\
\hline 6. & $\begin{array}{l}\text { To adapt s 15(4), SIA } 1985 \text { on factors to be considered in deciding whether the public interest in the disclosure outweighs the public interest in non- } \\
\text { disclosure, inter alia: } \\
\text { - whether the person had reasonable grounds to believe that the disclosure would be in the public's interest; } \\
\text { the public interest intended to be served by the disclosure; } \\
\text { the extent of the harm or risk of harm created by the disclosure; and } \\
\text { the existence of exigent circumstances justifying the disclosure, i.e., to avoid grievous bodily harm or death or violations or crimes against } \\
\text { humanity. }\end{array}$ \\
\hline
\end{tabular}

7. To repeal s 11(1) (d), WPA 2010, where this allows an agency to revoke the whistleblower protection on the person who disclosed the information which involves questioning the merits of government policy.

8. To adapt s 23(1) \& (2), Public Disclosure Act 2000 (NZ) prohibits employers from inserting an ousting clause which requires their employees/contractors to waive their right to disclose information.

9. To amend the Official Secret Act 1972 (OSA 1972) by adapting s 4(1), Security Information Act 1985 (Canada) that provides a narrower category of protected information i.e., the Act only applies to wrongful communication by a person who has in his possession or control any secret official code word, password, sketch, plan, model, article, note, document or information relating to a prohibited place.

10. To introduce the "Harm Test", requiring the prosecutor to prove that the release or disclosure of an official secret is for a purpose prejudicial to the safety or interest of the state.

11. To adapt s 3(1)(a) -(n), SIA 1985 that provides a statutory interpretation of what amounts to a purpose that is prejudicial to the safety or interest of the state, inter alia:

- $\quad$ to advance a political, religious or ideological purpose, objective or cause or to benefit a foreign entity or terrorist group;

- adversely affects the economic stability, the financial system or financial market without reasonable economic or financial justification

- impairs or threatens the capability of the armed forces/military service, or any part of it;

- impairs or threatens the ability of the Government or a Bank, to protect against, or respond to, economic or financial threats or instability;

- impairs or threatens the capability of the Government to conduct diplomatic or consular relations, or conduct and manage international negotiations:

- develops or uses anything that is intended to or can cause death or serious bodily injury to a significant number of people by whatever means.

12. To amend s 203A (1) and s 203A (2) of the Penal Code (Amendment) Act 2013 by adapting s 15(1), Security of Information Act 1985 (Canada) which provides a public interest defence for any person found guilty of an offence of purported or unauthorized communication or confirmation.

13. To adapt s 15(4), SIA 1985 on the statutory guidelines on factors to be considered by a judge in deciding whether the public interest in the disclosure outweighs the public interest in non-disclosure.

14. To amend s 7(1) of the Printing Presses and Publications Act 1984 (PPPA 1994) by omitting the word "in his absolute discretion" and to insert a provision that allows a judicial review to challenge the Minister's decision made under s 7(1), PPPA 1984.

15. To introduce statutory guidelines on the types of content in a publication that are likely:

- to be prejudicial to public order, morality, security, or

- alarm public opinion, or

- $\quad$ prejudicial to the public interest or national interest.

16. To amend s 8(2), PPPA 1994 which declares an offence for any person who issues, circulates and distributes any prohibited publication by inserting a public interest defence that allows a person to establish that the public interest in disclosure of the prohibited information outweighs the public interest in non-disclosure.

17. To amend s 10(1), Sedition Act 1948 on a court order to prohibit the issuing and circulation of prohibited publication by substituting the word "shown to the satisfaction of the court" with the word "proven", and omitting the phrases "be likely to" and "appears to", to read as follows:

Whenever on the application of the Public Prosecutor it is proven that the issue or circulation of a seditious publication is or if commenced or continued would lead to unlawful violence, or have the object of promoting a feeling of hostility between different classes or races of the community, the court shall make an order prohibiting the issuing and circulation of that publication.

18. To amend s 123 and s 124 Evidence Act 1950 (EA 1950) by adapting s 37(4.1) \& (5). Evidence Act 1985 (Canada) and s 69(2) (a)-(c), Evidence Act 2006 (NZ), vesting discretionary power on the Judge to order disclosure if the Judge considers that the disclosure in the proceeding of the privileged communication or confidential information is outweighed by the public interest, including for maintaining activities that contribute to or rely on the free flow of information. 
Table 3. Modalities to Address Legal Impediments to the Citizens' Right to Impart PSI In Malaysia (Non-Legislative Measures)

Non-Legislative Measures

1. To introduce a Policy on Internal Disclosure Procedures for PSI that imposes an obligation on Ministries, government agencies and statutory bodies to establish internal procedures to manage disclosures of PSI.

2. To adapt s 21(2) (a) \& (b), Access to Information Act 1985 (Canada) as a matter of policy that the head of government institutions cannot refuse disclosure of a record that contains an account of, or a statement of reasons for a decision that is made in the exercise of a discretionary power or an adjudicative function that affects the rights of a person.

3. To introduce Government Security Classifications by adapting Para 14, Part II, UK Government Security Classifications 2014 (GSC), which provides that:

- Information classified as "Official" is likely to be releasable unless it is subject to statutory exemptions.

- Where appropriate, official non-sensitive information should be published for re-use.

- All Official Information will be transferred to the National Archives as open records wherever possible, after 20 years and following the Public Records Act.

- Assessment of Disclosure of 'Secret' information is on a case-by-case basis. Some information might be releasable in a securely redacted format.

- 'Official Information' is to be distinguished from 'Official Sensitive' information. Where appropriate, non-sensitive information should be published for reuse.

4. To introduce Guidelines for Protection of Official Information and Government Security Classification System like New Zealand which provides guidelines for the head of a department regarding:

- $\quad$ unpublished official records relating to affairs of State that can be disclosed in Court; and

- the circumstances where the public interest would suffer by disclosure of the official communication.

5. To adapt Para 4.5, Government Security Classification System (NZ), which provides that government agencies should limit the duration of the protective marking and set up review procedures.

6. To adapt s 35(2), Freedom of Information Act 2000 (UK) as a matter of policy in that once the Government has decided on any given government policy, statistical information used to provide an informed background to the making of the decision may be disclosed under the Act.

\subsection{Conclusion}

This paper fulfils its objective to propose modalities to address legal impediments to the citizens' rights to impart PSI in Malaysia. The modalities proposed are of international standard as they are from the UK, Canada and New Zealand. Since the modalities incorporate both legislative and non-legislative measures, they serve as authoritative implementation tools to address legal impediments to the citizens' rights to impart PSI in Malaysia. The implementation of the modalities requires amendments to the Federal Constitution and impeding statutes. New legislation and policies should also be introduced.

Due to the time and budget constraints, the comparative analysis in this paper only covers three countries, and its survey only involves 40 respondents. In the future, the comparative analysis could be expanded to include other jurisdictions from ASEAN and nonCommonwealth nations, mainly the USA. Further, the survey could be extended to other government agencies, independent statutory bodies, as well as members of civil society and academic institutions not covered by this study. As this study focuses on the right to impart PSI, future research should focus on addressing legal impediments to the citizens' rights to seek and receive PSI.

As a legal study, this paper did not conduct a feasibility study to carry out the proposed modalities. However, since PSI in the present day mostly exists in digital format, it is anticipated that the right to impart PSI can be exercised through online media, hence being more cost-efficient. This paper also did not investigate the attitude and readiness among legislatures and civil servants, being the primary stakeholders in passing and implementing the proposed modalities. Thus, further study should be conducted to fill the gaps in this paper.

\section{Acknowledgments}

The authors thank the Ministry of Higher Education Malaysia and Universiti Teknologi MARA (UiTM) for their financial support under the grant 600-IRMI/FRGS 5/3 (005/2017). Special thanks to the Faculty of Law, UiTM for all its support in completing this study. The authors also thank the reviewers for their comments which improved this paper.

\section{References}

Amnesty International. (2015). Malaysia: Court Ruling on Sedition Act Yet Another Blow to Freedom. Retrieved from http://www.amnesty.org.au/news/comments/38165 Arona, E. (2018). A Theory of Citizenship Rights. Formal Membership in the Framework of (in)determinability of European Union Values. Nordicum-Mediterraneum, 13. doi:10.33112/nm.13.1.10

Centre for Media Pluralism and Media Freedom. (2016). Media Pluralism Monitor: Impediments to Access to Information in Europe (World Press Freedom Day 2016). Retrieved from http://journalism.cmpf.eui.eu/discussions/world-press-freedom-day-2016/

Daruwala, M. (2003). Open Sesame: Looking for the Right to Information in the Commonwealth. Retrieved from http://www.humanrightsinitiative.org/publications/chogm/chogm_2003/chogm_2003_report.pdf

Johan, S. (2013). Goodbye to Whistleblowers. The Star. Retrieved from

http://www.malaysianbar.org.my/members_opinions_and_comments/goodbye_to_whistleblowers.html

Lor, P. J., \& Britz, J. J. (2007). Is a Knowledge Society Possible Without Freedom of Access To Information? Journal of Information Science, 33(4), 387-397 
Mishra, A. (2013). Right to Information Empowerment or Abuse. Retrieved from http://lawmantra.co.in/right-to-information-empowerment-or-abuse-2/

Muhamad Izwan, I. (2014). Legal Hurdles in Freedom of Information in Malaysia. Retrieved from http://dx.doi.org/10.2139/ssrn.2470291

Peled, R., \& Rabin, Y. (2011). The Constitutional Right to Information. Columbia Human Rights Law Review, 42, 357

The Constitution Unit UCL. (2011). Freedom of Information and Data Protection. Retrieved from https://www.ucl.ac.uk/constitution-unit/research/foi/countries/malaysia

The Malaysian Insider. (2014). Replace Official Secrets Law with Freedom of Information Act, Urges Young Lawyers Group. Retrieved from http://www.themalaysianinsider.com/malaysia/article/replace-official-secrets-law-with-freedom-of-information-act-urges-young-la

Thiru, S. (2016). Misuse of the Communications and Multimedia Act Must End. Retrieved from https://www.malaysiakini.com/news/332239

Venkiteswaran, G. (2010). Freedom of Information in Malaysia: Turning the Secrecy Regime into a More Open One. Retrieved from http://www.asef.org/images/stories/ccs4/ws\%206_gayathry\%20venkiteswaran\%20malaysia.pdf 